\title{
Trurlia, a new Oriental genus of the tribe Cephenniini (Coleoptera: Scydmaenidae)
}

\author{
PAWEE JAŁOSZYŃSKI
}

Os. Wichrowe Wzgórze 22/13, 61-678 Poznań, Poland; e-mail: scydmaenus@yahoo.com

Key words. Coleoptera, Scydmaenidae, Cephenniini, Trurlia, new genus, Trurlia insana, new species, Oriental, Sumatra, Indonesia, Malaysia, taxonomy, morphology

\begin{abstract}
A new genus, Trurlia Jałoszyński, in the tribe Cephenniini (Scydmaenidae: Scydmaeninae) is described. The type species is T. insana sp. n. from Sumatra; females of an undescribed species are also reported to occur in W Malaysia. Trurlia most closely resembles Cephennomicrus Reitter, but it is the first genus of the Scydmaenidae with entirely fused antennomeres 10 and 11 , forming a large, oval, abruptly separated club. Based on a disarticulated female of Trurlia sp., the detailed morphology of the new genus is described and illustrated, and possible relationships with other genera of the tribe are discussed. Comments on evolution, polarity of characters and feeding strategy of the Cephenniini are included.
\end{abstract}

\section{INTRODUCTION}

Seven genera are currently recognized in the tribe Cephenniini: Cephennium Müller \& Kunze, 1822; Nanophthalmus Motschulsky, 1851; Pseudocephennium Reitter, 1883; Cephennodes Reitter, 1884; Cephennomicrus Reitter, 1907; Etelea Csiki, 1909; Paracephennium O’Keefe, 1999 and Hlavaciellus Jałoszyński, 2006. Another new Oriental genus closely allied to Cephennomicrus is described in a separate paper (Jałoszyński, in prep.), and several other, yet undescribed genera from SE Asia are known to the author. The tribe is defined primarily by the presence of unique suction discs on the labium, an adaptation for feeding on oribatid and uropodid mites (Schmid, 1988). The Cephenniini are also remarkable in having a very compact, usually oval body, with a weak constriction between the pronotum and elytra; the head retracted into the pronotum up to the posterior margin of eyes, without an occipital constriction and without tempora or with extremely short, barely noticeable tempora; and the presence of ocelli (Leschen $\&$ Beutel, 2004). The latter, however, may be absent in some genera. Recently a diverse array of male secondary sexual characters was discovered in Cephennodes, comprising complex and sometimes multiple modifications of various body parts (Jałoszyński, 2007a, b); similar but usually simpler structures can also be found in other genera of this tribe (reviewed by Jałoszyński, 2007a). Cephenniini consists of very small beetles, typically with a body length of 1.0-1.5 mm, with some species as small as $0.6 \mathrm{~mm}$ [e.g., Cephennomicrus minimus (Franz, 1983); the largest species measures $2.3 \mathrm{~mm}$ (Cephennodes hippopotamus Jałoszyński, 2007)]. The tribe has never been a subject of a comprehensive phylogenetic analysis, but similarities in some structures of the head capsule, mouthparts, ventrites and genitalia suggest a possible sister group relationship with the Eutheiini (Jałoszyński, 2007a). The biology of the cephenniine scydmaenids is poorly known; apart from some observations on the feeding strategy of Cephennium (Schmid, 1988) little is known about their behaviour. Species of all genera inhabit the forest floor and can be extracted from leaf litter or rotten wood; winged taxa are often caught in flight intercept traps. Many species are flightless, and in some genera adaptations to subterraneous microhabitats have evolved, including small eyes or light body pigmentation (Nanophthalmus, Etelea, some species of Cephennium).

All previously known species of the tribe have antennae composed of 11 antennomeres, as in all Scydmaenidae and the majority of Staphylinoidea. During my survey of world Cephenniini I have encountered a few specimens resembling members of Cephennomicrus, but with highly unusual, 10-segmented antennae, showing an odd, nearly histerid-like appearance due to a large, oval, abruptly separated club. Specimens of the genus seem to be very scarce, and among several thousand specimens from many localities within SE Asia only five individuals were found, including two species represented by four females from peninsular Malaysia, and a male from Sumatra. Herein a new genus is described, and details of its morphology relative to that of other cephenniines discussed.

\section{MATERIAL AND METHODS}

Specimens used in this study are deposited in the Staatliches Museum für Naturkunde, Stuttgart, Germany (SMNS), the National Museum of Nature and Science, Tokyo, Japan (NSMT) and the private collection of the author, Poznań, Poland (PCPJ). For comparative purposes, entirely disarticulated specimens of Cephennium majus Reitter, 1882 (Poland), Nanophthalmus sp. (Turkey), Cephennodes vafer Kurbatov, 1995 (Japan), Cephennomicrus nomurai (Jałoszyński \& Hoshina, 2003) (Japan) and Hlavaciellus sp. (Malaysia) were studied in detail; dry-mounted or partly dissected specimens of Etelea tenue Csiki, 1909 (Romania), Pseudocephennium sp. (Venezuela) and Paracephennium sp. (Ecuador) were also examined. 


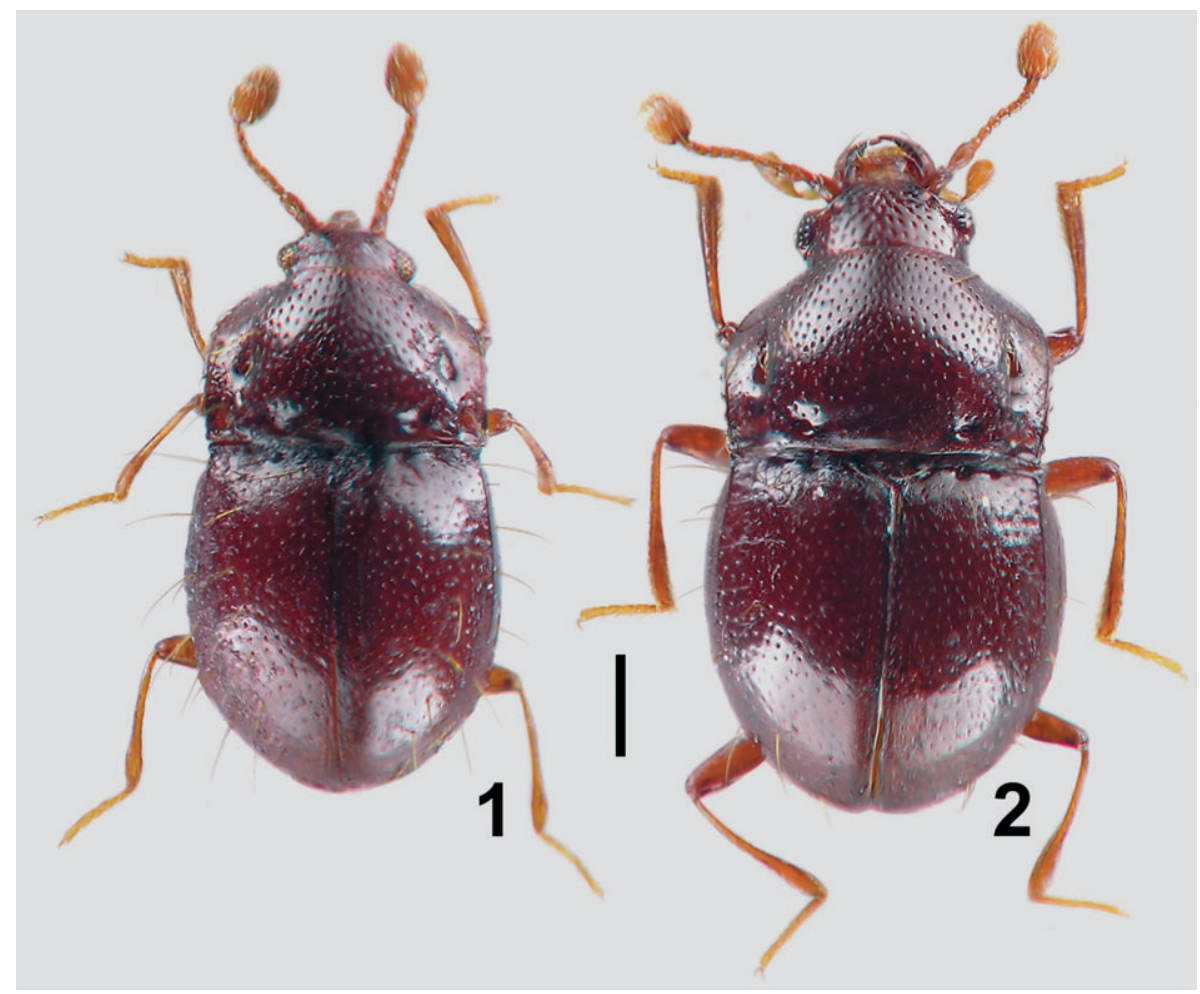

Figs 1-2. Trurlia gen. n., dorsal habitus. 1 - Trurlia insana sp. n., holotype male; 2 - Trurlia sp., female. Scale bar: $0.2 \mathrm{~mm}$.

Descriptions and illustrations of details of morphology are based on an entirely disarticulated female of an undescribed species of the new genus from Pahang (W Malaysia); the male terminal abdominal segments and aedeagus are those of the holotype male of Trurlia insana sp. n. Dry-mounted specimens were relaxed in warm water and dissected; when necessary body parts were macerated in potassium hydroxide; terminal abdominal segments were additionally stained with a glycerol solution of chlorazol black; structures of the skeleton were studied in glycerol or Canada balsam under a light microscope. The measurements and abbreviations used in the text are as follows: body length (BL) is a sum of the lengths of the head, pronotum and elytra measured separately; length of head (LH) was measured from a hypothetical line joining posterior margins of eyes to anterior margin of the frontoclypeal area; width of head (HW) includes eyes; length of antennae ( $\mathrm{AnL}$ ) was measured in ventral view; length of pronotum (PL) was measured along midline; width of pronotum (PW) was measured at the widest place; length of elytra (EL) was measured along suture, from a hypothetical line joining the humeral denticles to the apex; combined width of elytra (EW) was measured at the widest place; eytral index (EI) is length divided by combined width. All measurements are given in millimeters. Abdominal sternites are numbered starting from the first visible, basal sternite.

\section{RESULTS}

\section{Descriptions}

\section{Genus Trurlia Jałoszyński, gen. n.}

Type species. Trurlia insana Jałoszyński, sp. n.

\section{Diagnosis}

Trurlia differs from all other Cephenniini by numerous unique characters: antennae 10-segmented, with enlarged antennomeres 1-2, flagellum composed of slender compactly assembled antennomeres 3-9 of nearly equal widths, and very large, oval terminal antennomere $10+11$; antennomeres 1-9 bear very sparse setae, antennomere $10+11$ covered with dense setae; submentum much broader than long, fused with gula; gula subrectangular, covered densely with large oval punctures, only on short anterior part microreticulation composed of transverse cells; mandible with apical, subapical and median teeth; pronotum with well defined, subtriangular and blunt front angles visible in dorsal view; sculpture on pronotum composed of a transverse row of four ante-basal foveae, internal ones connected by a groove, and additionally with lateral ante-basal impressions and median lateral foveae; prosternal process very large, strongly projected ventrally and bent posteriorly at an obtuse angle, with ventral surface flattened and broad, and with a small anterior projection; mesocoxal cavities bordered posteriorly by an entire, foveate edge; metaventrite with lateral longitudinal carinae; katepisternum with lateral foveate ridges; mesoscutellum with a pair of foveae.

\section{Description}

Body (Figs 1, 2, 26). Colour brown. Small, very stout and strongly convex, with shallow constriction between pronotum and elytra, Vestiture on dorsum (Fig. 26) composed of very sparse, extremely long, strongly erect, curved setae.

Head (Figs 3-5, 11). Head capsule moderately large, broader than long, broadest at eyes, retracted into pronotum up to posterior margins of tempora; tempora short but well visible in dorsal view, provided with several short setae; vertex subrectangular, very broad and very short, convex; frons small, subtrapezoidal, convex, steeply sloping anteriorly; clypeus short, subrectangular 

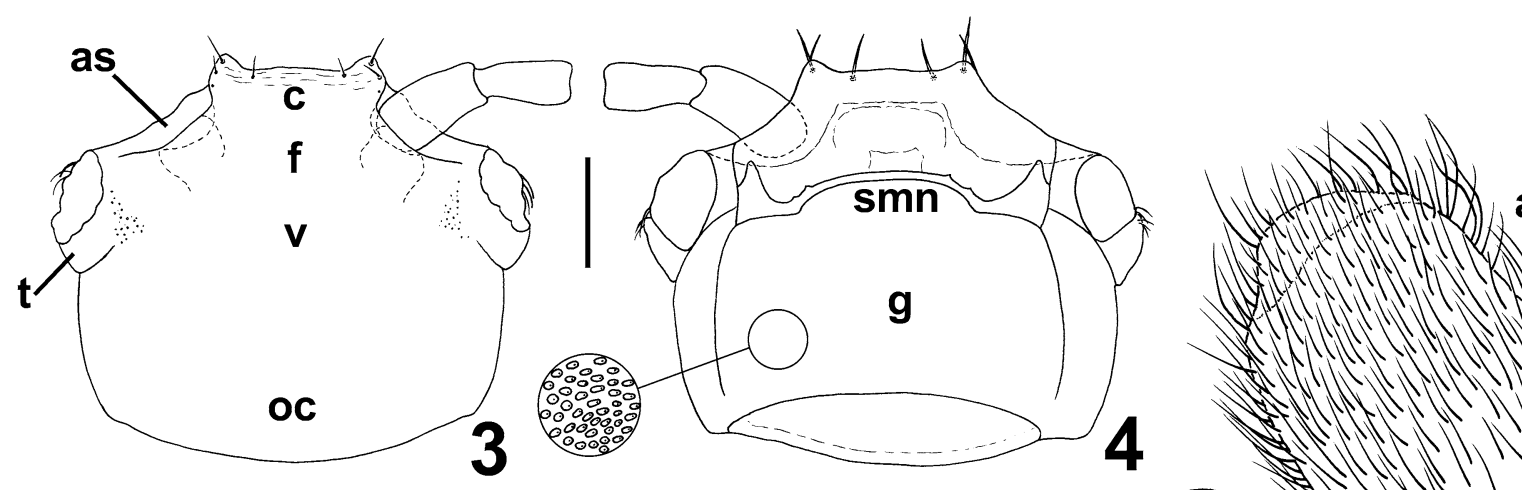

a10+11
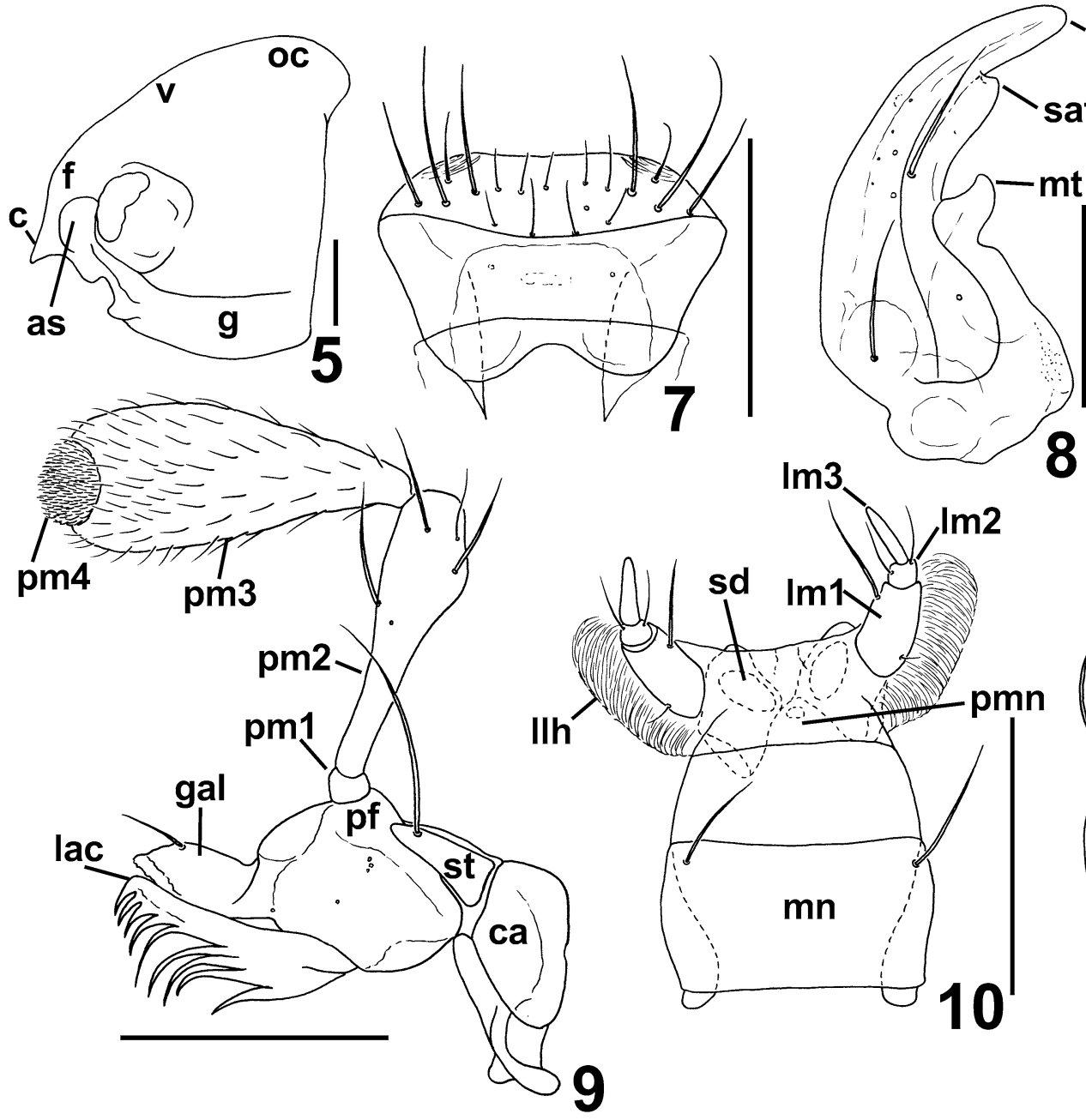

at

Figs 3-10. Trurlia sp., female, 3-5 - head capsule (mouthparts removed) in dorsal (3), ventral (4) and lateral (5) views; 6 - right antenna in dorsal view; 7 - labrum in dorsal view; 8 - left mandible in dorsal view; 9 - left maxilla in ventral view; 10 - labium in ventral view. Abbreviations: a1-10+11 - antennomere 1-10+11; as - antennal socket; at - apical tooth; c - clypeus; ca - cardo; $\mathrm{f}-$ frons; g - gula; gal - galea; lac - lacinia; llh - lateral lobe of hypopharynx; lm1-3 - labial palpomere 1-3; mn - mentum; mt median tooth; oc - occiput; pf - palpifer; pm1-4 - maxillary palpomere 1-4; pmn - prementum; sat - subapical tooth; sd - suction disc; smn - submentum; st - stipes; $\mathrm{t}$ - tempora; $\mathrm{v}$ - vertex. Scale bars: $0.1 \mathrm{~mm}$.

with each lateral part distinctly projected anteriorly and forming short subtriangular tooth provided with short setae; supraantennal tubercles small, weakly raised, with diffused margins; antennal sockets moderately large, each located below lateral margin of frons and adjacent to anterior margin of eye; eyes moderately large, kidneyshaped; gula and submentum fused and forming very large, subrectangular plate covered with microreticulation composed of fine, transverse cells on anterior part and with dense, oval pupillate punctures on remaining surface. Ocelli not found; possibly absent or obscured by coarse punctures covering vertex and frons; group of dense, small, possibly glandular pores can be seen near anterior margin of each eye. Antennae (Figs 6,11) mod- 

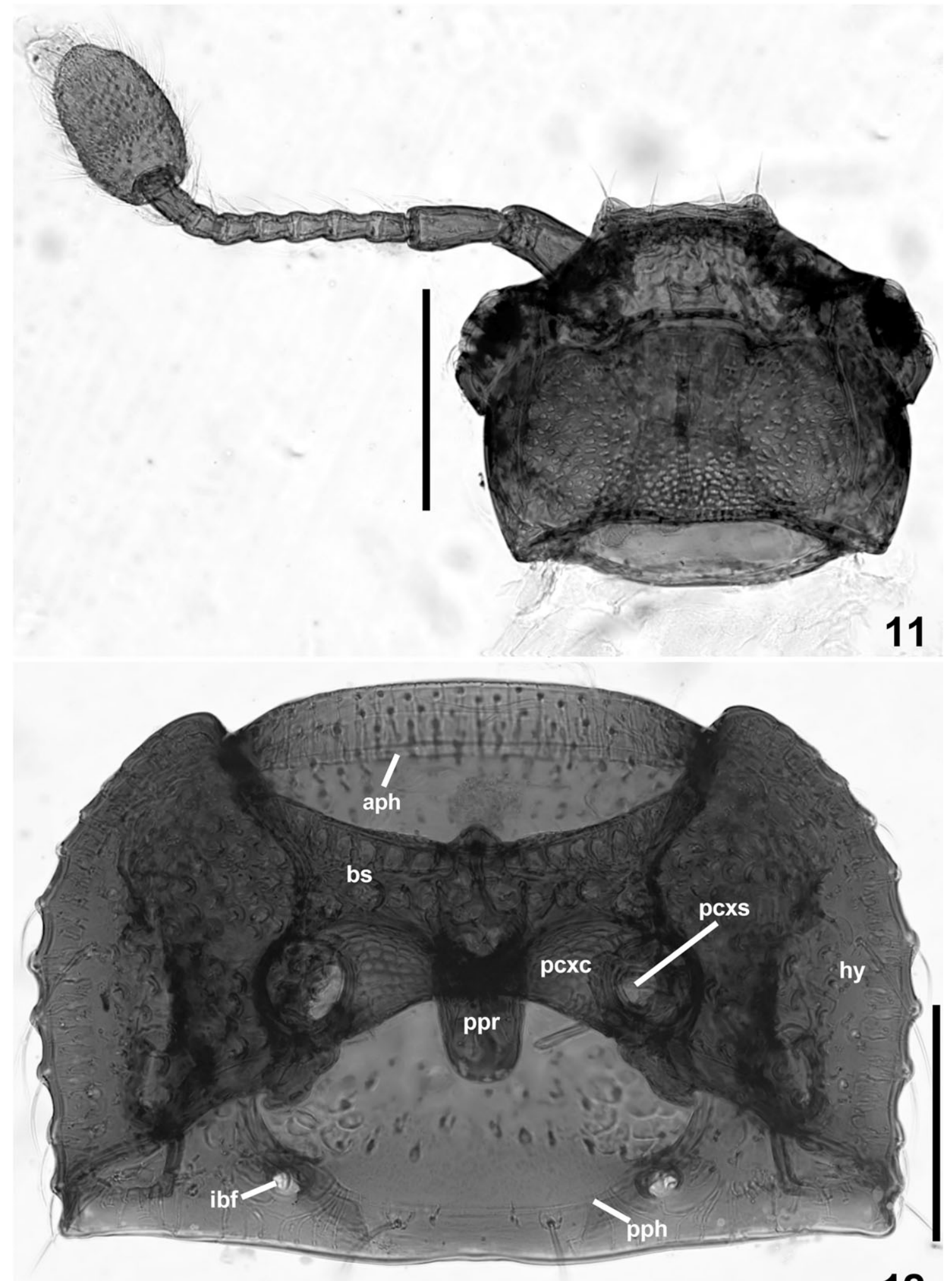

12

Figs 11-12. Trurlia sp., female. 11 - head and antenna (mouthparts removed) in ventral view; 12 - prothorax in ventral view. Abbreviations: aph - anterior phragma; bs - basisternum; hy - hypomeron; ibf - internal basal fovea; pcxc - procoxal cavity; pcxs procoxal socket; pph - posterior phragma; ppr - prosternal process. Scale bars: $0.2 \mathrm{~mm}$.

erately long, relatively slender and compact; antennomere 1 strongly elongate, broadest near base and slightly narrowing towards apex, with single long apical seta; antennomere 2 slightly smaller than 1 , broadest at apex, provided with 2-3 moderately long setae; antennomeres 3-8 are similar in shape, cylindrical or slightly broadened at apices, each much narrower and shorter than 2 , each with 2-6 moderately long setae; antennomere 9 about as 


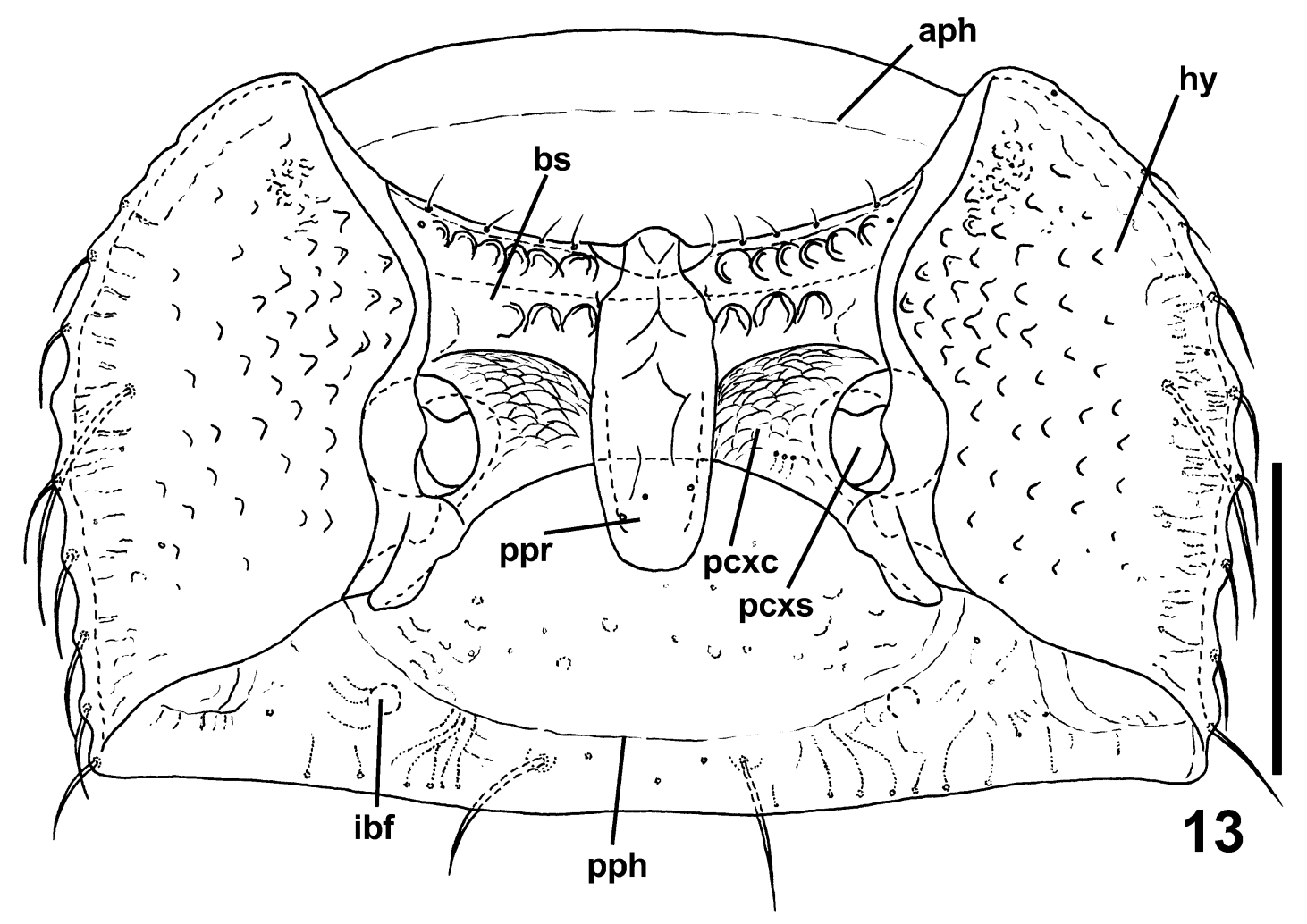

Fig. 13. Trurlia sp., female, prothorax in ventral view. Abbreviations: aph - anterior phragma; bs - basisternum; hy - hypomeron; ibf - internal basal fovea; pcxc - proxocal cavity; pcxs - procoxal socket; pph - posterior phragma; ppr - prosternal process. Scale bar: $0.2 \mathrm{~mm}$.

wide as 8 but distinctly longer, its apical part concealed by concave base of club, provided with several moderately long setae; antennomeres 10 and 11 fused and forming very large, oval club with indistinct constriction near middle marking where fused and a subapical constriction separating short apical part, club is covered with dense, moderately long, suberect and erect sensilla.

Mouthparts. Labrum (Fig. 7) broader than long, with apical margin nearly straight in middle, strongly rounded at sides, lateral margins strongly convergent toward base; apical part of labrum with lateral group of three long and one short seta on each side and two transverse rows of 5 and 4 short setae medially. Epipharynx rudimentary, with small groups of setae located laterally and subapically. Mandible (Fig. 8) subtriangular in shape, with broad base that narrows towards apex, with long but blunt apical tooth, small and blunt subapical tooth and moderately long, curved and also blunt median tooth separated from basal mesal cutting edge by subtriangular emargination; dorsal surface of mandible with two long setae, basal part of mesal edge bears group of dense, very small punctures or pores. Maxilla (Fig. 9) composed of elongate, subtriangular stipes provided with very long subapical seta; elongate palpifer; elongate lacinia provided with row of several robust, sharp teeth along internal margin; and elongate galea with moderately long seta located subapically on external margin (internal teeth or setae on galea of both maxillae broken off on the specimen studied). Maxillary palpus large, with very small, subcylindrical and asetose palpomere 1; very long, clavate palpomere 2 bearing several moderately long setae apically; large, elongate palpomere 3 strongly broadening toward truncate apex, covered with numerous moderately dense, short setae; and very short and broad palpomere 4, densely covered with short setae. Labium (Fig. 10) with darkly sclerotized, subrectangular mentum provided with pair of long lateral distal setae; prementum short, with pair of oval suction discs on anterior surface; labial palpi three-segmented, with large, elongate and subcylindrical palpomere 1 bearing single long subapical seta; palpomere 2 very short, subcylindrical, with two long apical setae; and subconical, elongate and asetose palpomere 3; lateral lobes of hypopharynx moderately large, densely setose.

Prothorax (Figs 12, 13, 16). Pronotum in dorsal view broader than long, with anterior margin distinctly separated from well defined, subtriangular, blunt front angles; lateral margins distinctly serrate with entire, sharp lateral edges; hind angles well defined, blunt; posterior margin of pronotum with three very shallow emarginations. Pronotum with ante-basal transverse row of four foveae, internal pair connected by groove, additionally with large lateral impression near each hind angle and pair of deep, elongate lateral foveae located near middle of lateral margin of pronotum. Hypomera very large, slightly concave; basisternum short; procoxal cavities as long as about half length of sternum, covered with microsculpture composed of transverse, approximately hexagonal cells; 


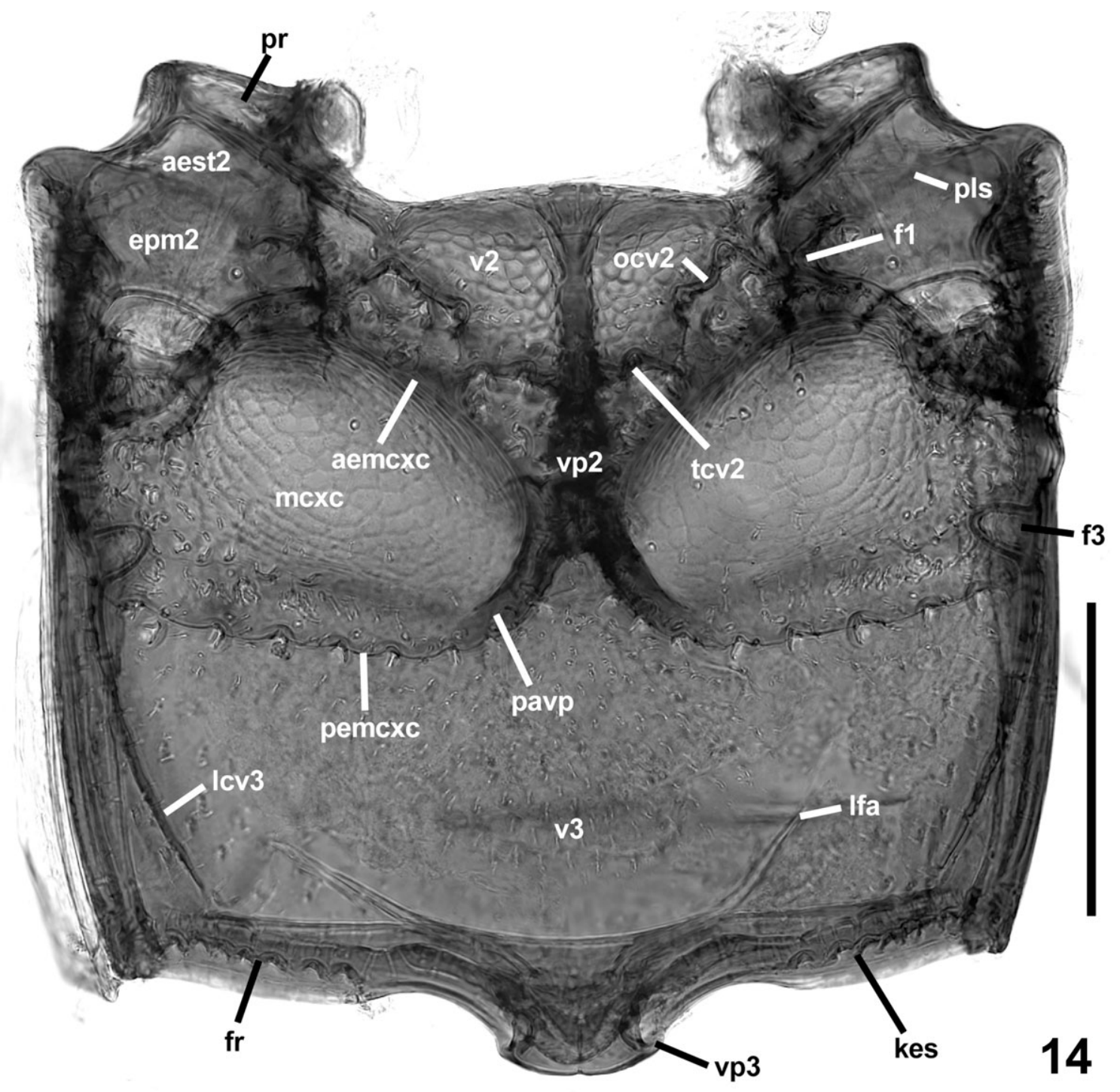

Fig. 14. Trurlia sp., female, meso- and metathorax in ventral view. Abbreviations: aemcxc - anterior edge of mesocoxal cavity; aest 2 - mesanepisternum; epm2 - mesepimeron; f1 - internal mesepimeral fovea; $\mathrm{f} 3$ - lateral metaventral fovea; fr - foveate ridge; kes - katepisternum; lcv3 - lateral carina of metaventrite; lfa - lateral furcal arm; mcxc - mesocoxal cavity; ocv2 - oblique carina of mesoventrite; pavp - posterior arm of mesoventral process; pemcxc - posterior edge of mesocoxal cavity; pls - pleural suture; pr prepectus; tcv2 - transverse carina of mesoventrite; v2 - mesoventrite; v3 - metaventrite; vp2 - mesoventral process; vp3 metaventral process. Scale bar: $0.2 \mathrm{~mm}$.

procoxal sockets entirely closed; prosternal intercoxal process very large, in lateral view strongly projected ventrally and bent posteriorly at an obtuse angle, with anterior margin expanded and forming small projection, ventral surface of prosternal process flattened and broad. Sculpture on ventral part of prothorax is coarse, composed of transverse rows of large foveate punctures on basisternum, indistinct longitudinal and oblique carinae on prosternal process and small, foveate punctures on hypomera.

Pterothorax (Figs 14, 15, 17-19, 21, 22). Mesoventrite (Figs 14, 15, 17) relatively short, divided by foveate transverse and oblique carinae into large anterior part and small posterior part; sides of anterior part of mesoventrite covered with microsculpture composed of small, approximately hexagonal cells; posterior and lateral parts of mesoventrite bear several large, foveate punctures.
Mesoventral intercoxal process elongate, weakly expanded ventrally, narrow in anterior half and distinctly broadened posteriorly, with well defined, short and divergent posterior arms and with vertical foramen closed (i.e., marked only as thin circular area well visible in lateral view in transparent mount). Mesanepisternum transversely extended, divided by moderately distinct lateral ridge into narrow internal part and broader, strongly concave lateral part; mesepimeron very large, divided by longitudinal lateral ridge into large ventral part and smaller lateral part not visible in ventral view; ventral part of mesepimeron bears internal mesepimeral fovea located on internal anterior part adjacent to mesanepisternum and mesoventrite; lateral part of mesepimeron bears external mesepimeral fovea and is indistinctly delimited from lateral part of metaventrite. Mesocoxal cavities very large, transversely oval, covered with dense mesh of approxi- 


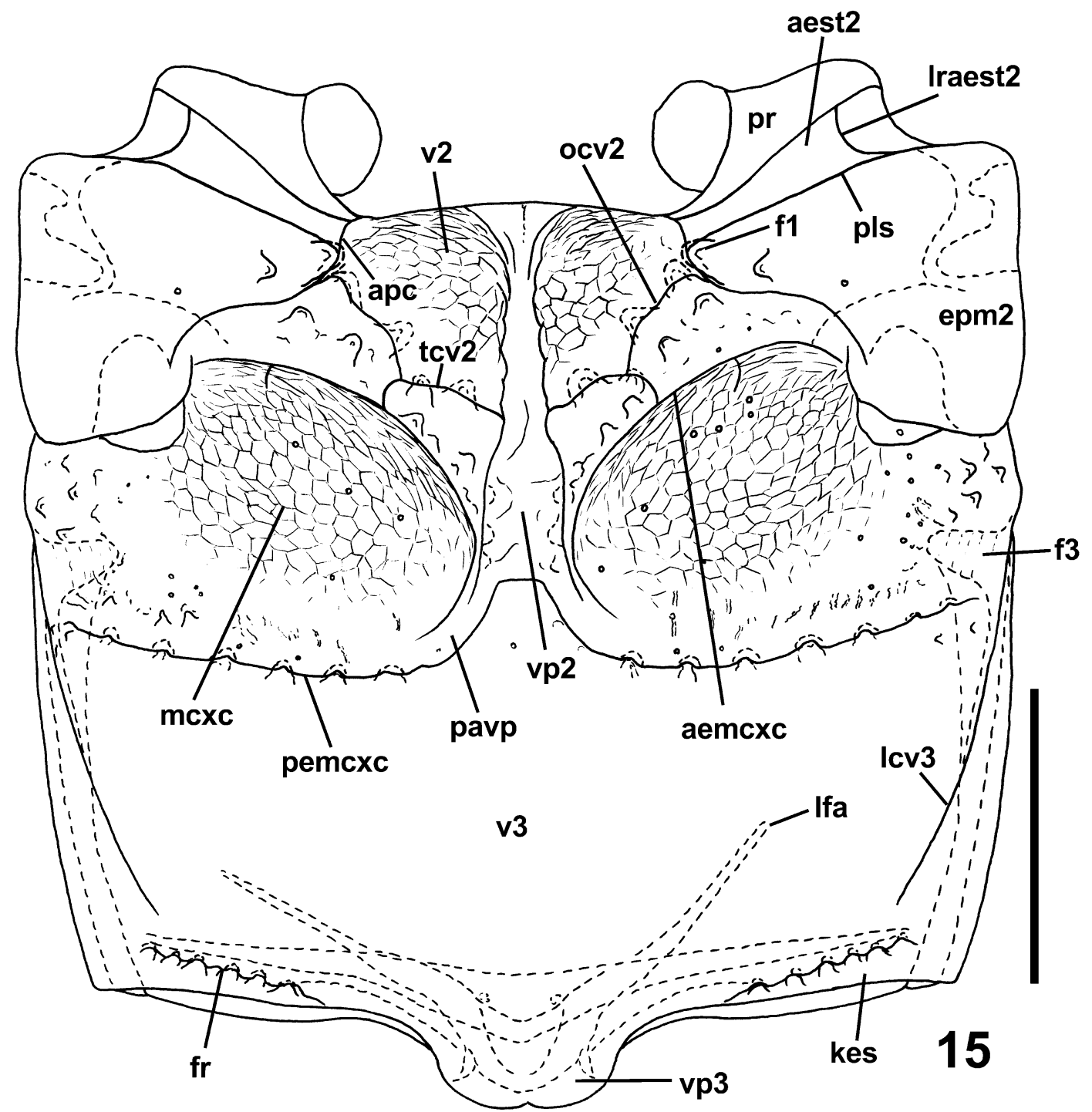

Fig. 15. Trurlia sp., female, meso- and metathorax in ventral view. Abbreviations: aemcxc - anterior edge of mesocoxal cavity; aest2 - mesanepisternum; apc - anapleural cleft; epm2 - mesepimeron; f1 - internal mesepimeral fovea; f3 - lateral metaventral fovea; fr - foveate ridge; kes - katepisternum; lcv3 - lateral carina of metaventrite; lfa - lateral furcal arm; lraest2 - lateral ridge of mesanepisternum; mcxc - mesocoxal cavity; ocv2 - oblique carina of mesoventrite; pavp - posterior arm of mesoventral process; pemcxc - posterior edge of mesocoxal cavity; pls - pleural suture; pr - prepectus; tcv2 - transverse carina of mesoventrite; v2 mesoventrite; v3 - metaventrite; vp2 - mesoventral process; vp3 - metaventral process. Scale bar: $0.2 \mathrm{~mm}$.

mately hexagonal cells, delimited posteriorly by entire posterior edge bearing row of foveae and connected to internal margins of posterior arms of mesoventral process. Metaventrite posterior to mesocoxal cavities about twice as broad as long, convex, with slightly oblique longitudinal lateral carina on each side; in lateral view (Fig. 17) lateral carina of metaventrite anteriorly adjacent to deep lateral metaventral fovea; posterior margin of metaventrite bears broad but short metaventral process with shallowly emarginate, convexly biarcuate posterior margin; katepisternum bears slightly oblique, transverse ridge with row of small foveae; metanepisternum and metepimeron long and narrow. Metafurca has a very short stalk and long, narrow, strongly divergent lateral furcal arms. Mesonotum (Figs 19, 21) moderately large, with subrectangular mesoscutum and subtrape- zoidal mesoscutellum bearing pair of large mesoscutellar foveae, mesoscutellum well visible in intact specimens. Metanotum (Figs 18, 22) strongly reduced, only its anterior part darkly sclerotized, with very short alacristae; metascutum membranous, structures posterior to metascutum reduced and indiscernible.

Legs. All are moderately long and slender, typical for Cephenniini, without any peculiar characters.

Elytra (Figs 20,23). Each elytron is oval with rounded apices. Base has two distinct, asetose foveae; moderately distinct, blunt humeral denticle; and long, longitudinal humeral carina. In transparent mounts (Fig. 20) dense, puncture-like structure visible, not correlated with punctures visible in dry-mounted specimens. Hind wings missing. 


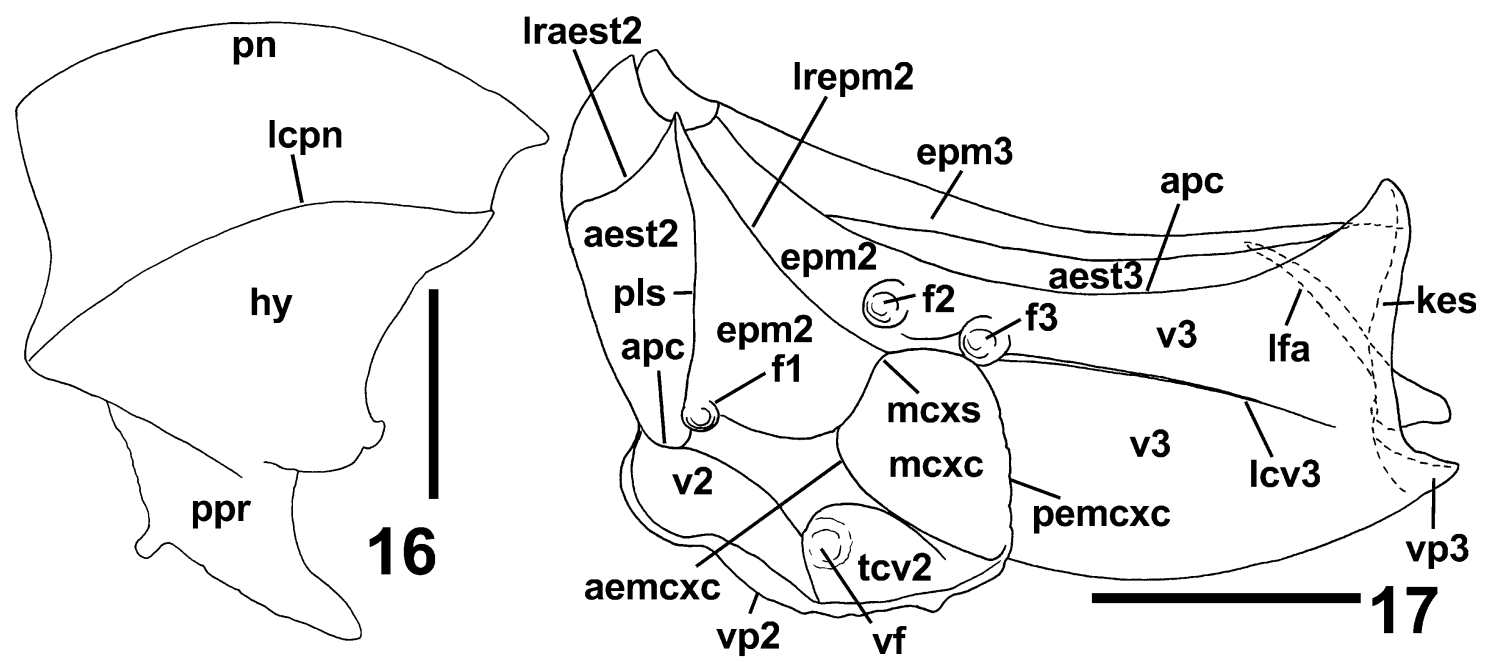

Figs 16-17. Trurlia sp., female. 16 - prothorax in lateral view; 17 - ventral and lateral parts of meso- and metathorax in lateral view. Abbreviations: aemcxc - anterior edge of mesocoxal cavity; aest2 - mesanepisternum; aest3 - metanepisternum; apc anapleural cleft; epm 2 - mesepimeron; epm 3 - metepimeron; $\mathrm{f} 1$ - internal mesepimeral fovea; $\mathrm{f} 2$ - external mesepimeral fovea; $\mathrm{f} 3$ lateral metaventral fovea; hy - hypomeron; kes - katepisternum; lcpn - lateral carina of pronotum; lcv3 - lateral carina of metaventrite; lfa - lateral furcal arm; lraest 2 - lateral ridge of mesanepisternum; lrepm2 - lateral ridge of mesepimeron; mcxc - mesocoxal cavity; mcxs - mesocoxal socket; pemcxc - posterior edge of mesocoxal cavity; pls - pleural suture; pn - pronotum; ppr - prosternal process; tcv2 - transverse carina of mesoventrite; v2 - mesoventrite; v3 - metaventrite; vf - vertical foramen; vp2 - mesoventral process; vp3 - metaventral process. Scale bars: $0.2 \mathrm{~mm}$.

Abdomen (Fig. 24). Six abdominal sternites are visible; sternites 1 and 6 distinctly longer than other sternites; only apex of pygidium exposed.

Female terminal abdominal segments (Fig. 25). Ovipositor lightly sclerotized, nearly membranous; paraproct broad, bearing on each side elongate valvifer with densely setose distal margin; proctiger approximately heart-shaped, with densely setose posterior margin.

Male terminal abdominal segments (Figs 27-29). Tergite 9 (Fig. 27) elongate, with long distal lateral arms, each provided with single apical seta; sternite 9 (Fig. 28) elongate, subtrapezoidal, with two pairs of apical setae; tergite 10 (Fig. 29) semielliptical, without setae.

Aedeagus (Figs 30, 31). Median lobe thin-walled, symmetrical, elongate, with apical part separated from basal part; internal armature relatively simple, composed of tubular subapical structure; orifice located basally. Base of parameres is simple and lacks lateral lobes; parameres free, slender and long, with subapical setae.

\section{Taxonomic comments}

Each character given in the diagnosis is unique for this genus, and not known in any other member of the Cephenniini, which makes Trurlia the most conspicuous genus of the tribe, defined by the largest suite of autapomorphies. Additionally, Trurlia has remarkable foveate sculpture on the hypomera, basisternum, mesoventrite and anterior lateral parts of the metaventrite. Transparent mounts of the elytra revealed another unique feature - a dense pattern of circular, puncture-like structures not visible in dry specimens.

Besides the striking autapomorphies listed in the diagnosis, Trurlia differs from other genera of the tribe in several additional characters. The new genus has six well visible abdominal sternites. This character (shared with Cephennium, Nanophthalmus, Etelea, Cephennodes, Cephennomicrus and Hlavaciellus) clearly differentiates Trurlia from Neotropical Pseudocephennium and Paracephennium, which are described as having only three visible abdominal sternites (Reitter, 1983; O’Keefe, 1999). In fact, the abdomen in the two latter genera has six externally visible sternites, but some of them are strongly shortened and concealed by a marginal fringe of long and dense setae on the preceding segment, so that the actual number of sternites can be correctly evaluated only in transparent mounts. Important characters differentiating Trurlia from most of the Cephenniini are also two basal pits on each elytron (shared only with some Cephennomicrus), and the large prosternal process with a strongly flattened ventral surface and a small anterior projection well visible in lateral view (shared only with some undescribed Oriental genera allied to Cephennomicrus). Pseudocephennium and Paracephennium have rudimental basal pits on the elytra (barely discernible on drymounted specimens under a light microscope); Cephennium, Nanophthalmus, Etelea, Cephennodes and Hlavaciellus have a single, well visible basal pit on each elytron (or two connected pits sharing one circular opening; see Discussion), and the prosternal process is either missing (Pseudocephennium, Cephennium and Nanophthalmus), very short (Etelea and Hlavaciellus), long but very narrow (Paracephennium), or long and moderately broad, but not flattened and without the additional anterior projection (Cephennodes and Cephennomicrus). Trurlia is most similar to Cephennomicrus and some undescribed Oriental genera morphologically close to Cephennomicrus (see Discussion), but can be easily discriminated by characters given in the above diagnosis. 


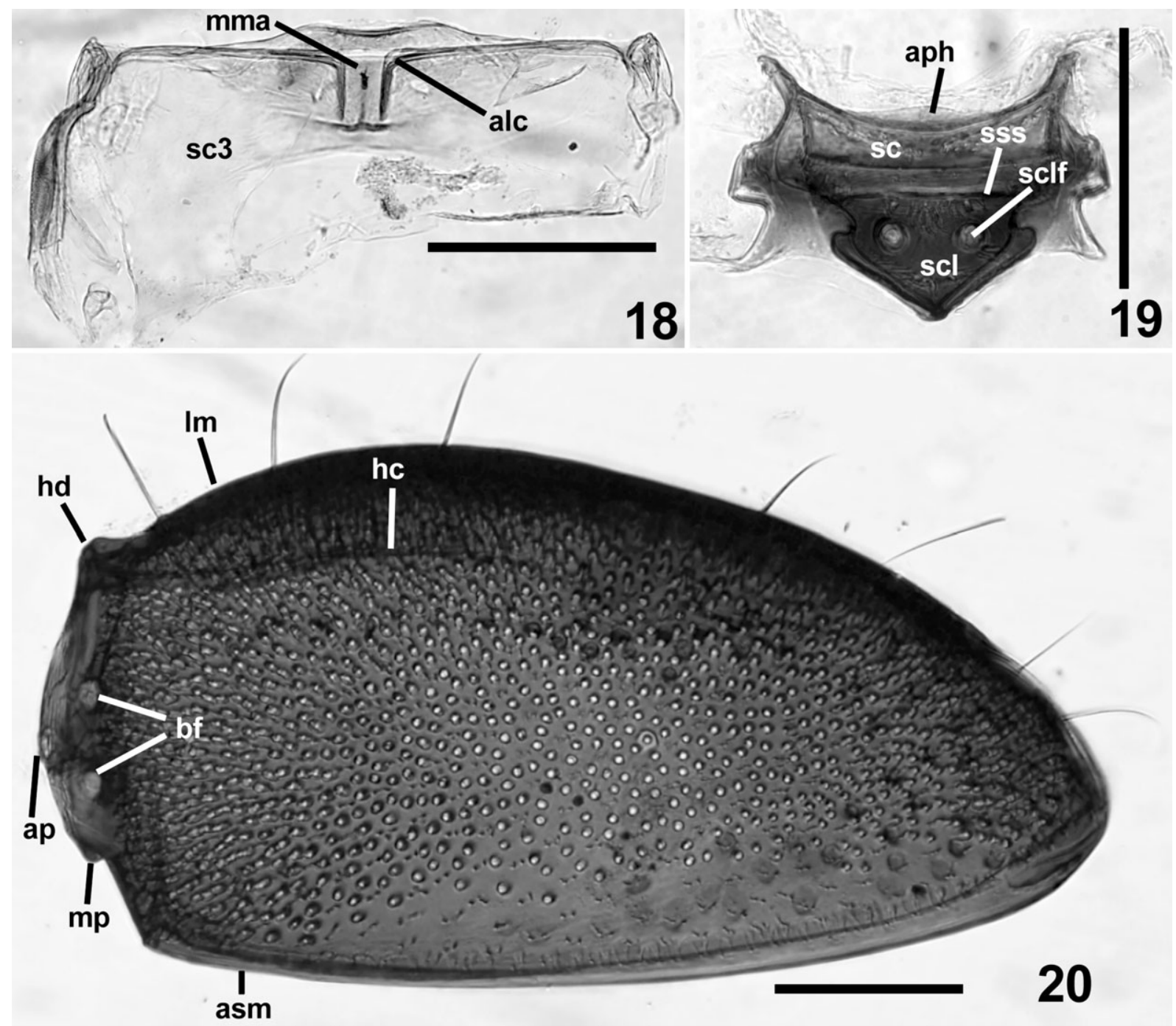

Figs 18-20. Trurlia sp., female. 18 - metanotum in dorsal view; 19 - mesonotum in dorsal view; 20 - right elytron in dorsal view. Abbreviations: alc - alacrista; ap - articulating process of elytral base; aph - anterior phragma; asm - adsutural margin; bf - basal fovea; hc - humeral carina; hd - humeral denticle; lm - lateral margin; mma - median membranous area; mp - mesal process of elytral base; sc - mesoscutum; sc3 - metascutum; scl - mesoscutellum; sclf - mesoscutellar fovea; sss - scuto-scutellar suture. Scale bars: $0.2 \mathrm{~mm}$.

Etymology. The name Trurlia is derived from Trurl, a character featured by a recently deceased Polish science-fiction author and philosopher Stanisław Lem, and is named in tribute to his extraordinary imagination that populated the Universe with a plethora of fantastic live beings; Trurlia with its bizarre appearance fits well into his imaginary world. Gender is feminine.

Distribution. Oriental: Indonesia (Sumatra), W Malaysia (Pahang).

\section{Trurlia insana sp. $\mathbf{n}$.}

Figs 1, 26-31

\section{Diagnosis}

Diagnostic characters of this species agree with those given for the genus; the unique aedeagus must be examined to confirm identification.

\section{Description (male)}

Body (Fig. 1). Small (BL 1.28), very stout and very convex, shallowly but distinctly constricted between pro- notum and elytra; pigmentation dark brown with slightly reddish shade, vestiture light brown.

Head. Head capsule much broader than long, broadest at eyes, HL 0.18 , HW 0.33 ; tempora very short, barely noticeable; vertex regularly convex; frons slightly flattened, its anterior part distinctly steeper towards convex clypeus compared with posterior part; supraantennal tubercles small, weakly raised, diffused; eyes very large, strongly convex, coarsely faceted, in lateral view nearly semicircular, with emarginate posterior margin. Punctures on vertex and frons very small but deep and relatively sharply marked, separated by spaces equal to or slightly shorter than diameter of punctures; dorsal surface of head glabrous except for tempora bearing several short and laterally erect setae and anterior part of clypeus provided with several long, anteriorly erect setae. Antennae short, with flagellum compact and slender except for strongly enlarged terminal antennomere forming sharply delimited club, AnL 0.43, first antennomere $2.2 \times$ as long as broad; 


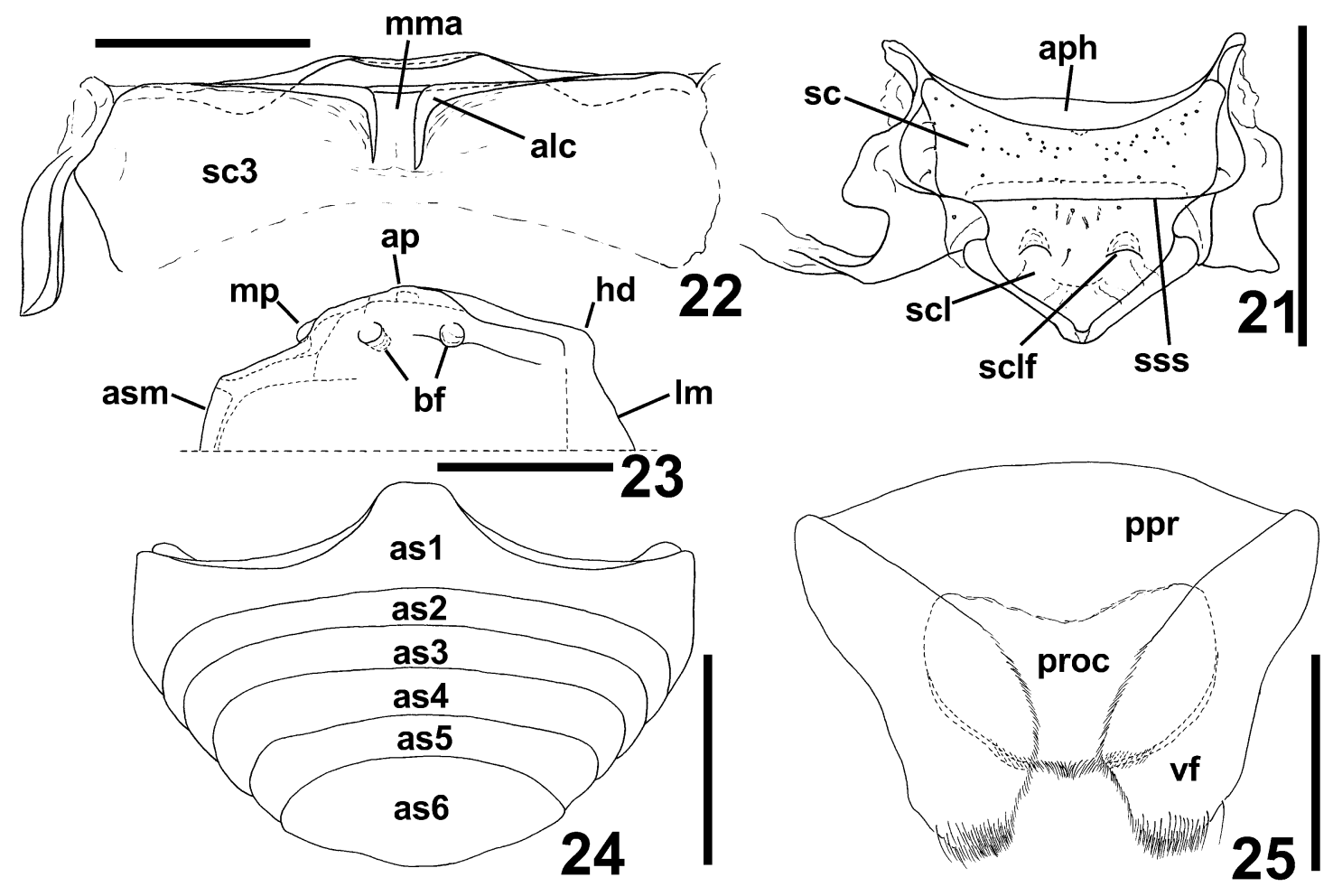

Figs 21-25. Trurlia sp., female. 21 - mesonotum in dorsal view; 22 - metanotum in dorsal view; 23 - base of right elytron in dorsal view; 24 - abdomen in ventral view; 25 - ovipositor in ventral view. Abbreviations: alc - alacrista; ap - articulating process of elytral base; aph - anterior phragma; as1-6 - abdominal sternites; asm - adsutural margin; bf - basal fovea; hd - humeral denticle; $1 \mathrm{~m}$ - lateral margin; mma - median membranous area; $\mathrm{mp}$ - mesal process of elytral base; ppr - paraproct; proc - proctiger; sc - mesoscutum; sc3 - metascutum; scl - mesoscutellum; sclf - mesoscutellar fovea; sss - scuto-scutellar suture; vf - valvifer. Scale bars: $0.2 \mathrm{~mm}$.

second slightly narrower and shorter than first, $2 \times$ as long as broad; third-ninth of equal width, third much narrower and shorter than second, subquadrate; fourth $1.1 \times$ as long as broad; fifth $1.2 \times$ as long as broad; sixth $1.1 \times$ as long as broad; seventh $1.2 \times$ as long as broad; eighth $1.1 \times$ as broad as long; ninth $1.2 \times$ as long as broad, its apical part hidden in concave base of club, which is slightly more than $3 \times$ as broad as preceding flagellum, twice as broad as long, with shallow, diffused constriction slightly anterior to middle and another indistinct constriction close to apex. First antennomere bears single, very long and erect seta on internal apical margin, antennomeres 2-9 each with several moderately long, suberect setae; club provided with dense, moderately long, suberect sensilla.

Prothorax. Pronotum in dorsal view approximately subrectangular, very convex in middle and with distinctly, but moderately flattened sides, broadest slightly before middle, PL 0.38, PW 0.58; anterior margin strongly convex, regularly rounded; anterior angles well visible in dorsal view, blunt; lateral margins distinctly serrate, strongly rounded in anterior half, nearly straight in posterior half, barely noticeably convergent toward nearly right hind angles of pronotum; posterior margin nearly straight; base of pronotum with two pairs of small and shallow but distinct circular pits, internal pits connected by transverse groove; additionally pronotum bears large and shallow but well delimited impression near each hind angle and elongate, subtriangular, deep and sharply delimited lateral pit near middle. Punctures on disc very distinct, moderately large, deep, sharply marked and slightly elongate, distances between punctures on median part of pronotum equal to or slightly shorter than puncture widths, flattened sides of pronotum covered with punctures distinctly smaller, shallower and denser than those in middle. Setation of pronotum composed only of very long, sparse and strongly erect setae distributed as in Fig. 26.

Elytra. Each elytron oval, short, slightly more convex than median part of pronotum, broadest distinctly before middle; EL 0.73, EW 0.65, EI 1.12; humeral denticles small but well marked; humeral carinae narrow, as long as half length of elytra; two basal pits on each elytron small but deep and well visible; apices of elytra separately rounded. Punctures on elytra much smaller, shallower and sparser than those on median part of pronotum, slightly unevenly distributed, those on median part of each elytron separated by spaces $1.5-3 \times$ as long as puncture diameters; setae similar to those on pronotum, distributed as in Fig. 26. Hind wings entirely missing.

Mesoscutellum. Scutellum is well visible in beetles in natural position, triangular, moderately large, with pair of shallow pits.

Legs. All tibiae slightly curved; metatibiae with abruptly swollen apical fourth; remaining parts without any particular characters.

Venter. Structures of ventrites as described in generic description; prosternum and prosternal process covered 

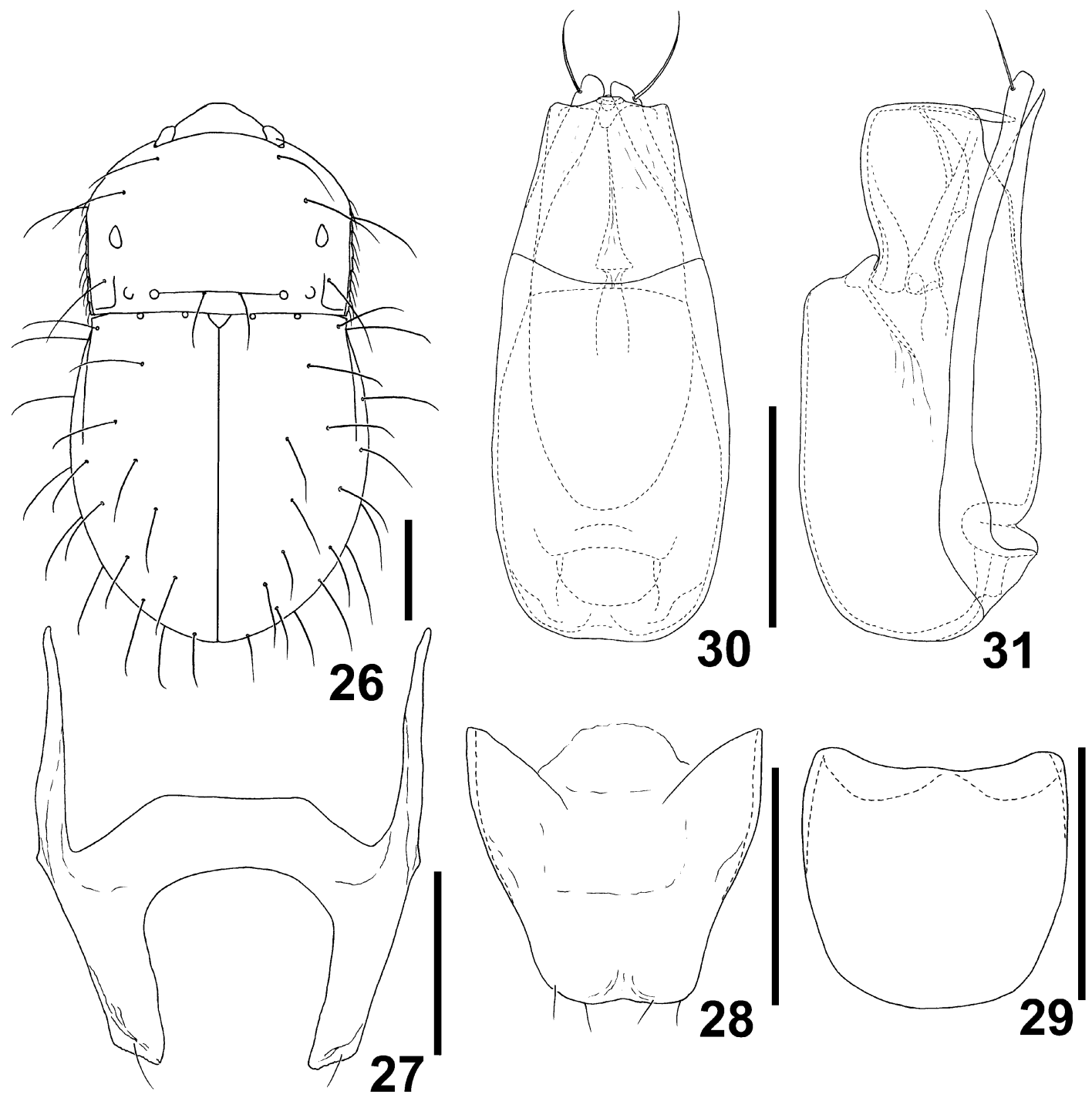

Figs 26-31. Trurlia insana sp. n., holotype male. 26 - body outline and chaetotaxy in dorsal view; 27 - tergite 9 in dorsal view; 28 - sternite 9 in ventral view; 29 - tergite 10 in dorsal view; 30-31 - aedeagus in ventral (30) and lateral (31) views. Scale bars: 26 : $0.2 \mathrm{~mm} ; 27-31: 0.1 \mathrm{~mm}$

with large, sparse punctures; median part of metaventrite with very small but dense and distinct punctures becoming gradually larger, deeper and sparser toward lateral margins of ventrite.

Aedeagus (Figs 30, 31). Median lobe $0.25 \mathrm{~mm}$ in length, symmetrical, elongate, divided into oval basal part and shorter apical part subtrapezoidal in shape in ventral view; apex truncate, in lateral view with elongate, slender dorsal projection; internal armature lightly sclerotized, composed of tubular structure located in apical part of median lobe; parameres long and slender, each with single subapical seta.

Type material. Holotype male: "W-Sumatra: Bukittinggi, Lembah Anai 16.10.1991 $800 \mathrm{~m}$ leg. A. RIEDEL" [yellow, printed] (SMNS).

Etymology. The Latin adjective insanus adopted as a specific epithet means (among others) outrageous, monstrous, extravagant, excessive; also mad, insane, that acts like a madman; or that causes madness. It refers to the extraordinary morphology with a number of very unusual characters.
Distribution. Oriental Region: Indonesia (Sumatra).

Remarks. The only known male of Trurlia insana is very similar to females belonging to an undescribed species from W Malaysia (Fig. 2) (deposited in NSMT and PCPJ). This similarity suggests that the new genus may have very uniform external morphology, and the characters associated with the aedeagus are important for species identifications.

\section{DISCUSSION}

Trurlia with its large set of autapomorphies seems to be a highly derived offshoot of the Cephenniini, and most likely of the Cephennomicrus lineage. The latter consists of Cephennomicrus and several undescribed Oriental genera (Jałoszyński, in prep.); together with Trurlia they all share the following combination of synapomorphies: Four ante-basal foveae on the pronotum, of which the internal pair is often connected by a transverse groove; two basal pits on each elytron (reduced to one in some 
taxa); entirely closed procoxal sockets; large and posteriorly bent procoxal process; and male and female terminal abdominal segments and aedeagi of similar design. Detailed morphology of Cephennomicrus will be described elsewhere (Jałoszyński, in prep.), and detailed comparative morphology of the Old World Cephenniini will also be analyzed in a separate paper. However, even at the current, preliminary stage in the study of this tribe, some genera can be grouped into distinct lineages (e.g., Cephennium + Nanophthalmus), and a close relationship between Trurlia and Cephennomicrus seems very plausible.

In most representatives of Cephennomicrus the dorsum is covered with uniformly short and dense vestiture, but in some species [e.g., C. cactiformis (Jałoszyński \& Hoshina, 2003)] there are several long, erect setae on the pronotum and elytra, with some of them located along lateral margins and near middle of the basal part of the pronotum. The short, basic vestiture tends to be shorter, and is visible in C. taiwanensis (Jałoszyński, 2004), and even more strikingly in $C$. simplex Jałoszyński \& Nomura, 2008. In the latter species, the basic vestiture is reduced to sparse, very short and nearly recumbent setae. Finally, in some undescribed Oriental species of Cephennomicrus, the basic vestiture is entirely missing, and the pronotum and elytra bear only very long, sparse and strongly erect setae distributed in a similar way as those in Trurlia. No other genus of the tribe shows a similar tendency to reduce the vestiture; only in some species of Cephennodes (e.g., C. guadunanus Jałoszyński, 2007 or C. penicillatus Jałoszyński, 2007) are there a few long setae among short and dense basic vestiture on the elytra, but they are not as long as those in Trurlia and Cephennomicrus, and they differ in distribution.

In some species of Cephennomicrus [e.g., C. okinawanus (Jałoszyński, Arai \& Arai, 2004)], antennomere 9 is relatively small, nearly as small as preceding flagellomeres, and two terminal antennomeres are strongly enlarged. This might have been a starting point for fusion of antennomeres 10 and 11, as seen in Trurlia. Interestingly, also in Cephennomicrus, antennomere 11 is commonly slightly constricted subapically. This constriction divides the antennomere into a large, approximately cylindrical basal part, and a small, subconical apical part; this division is sometimes accentuated by a ring of short setae. On the antennae of Trurlia sp. studied in transparent mount and illustrated in Fig. 6, the apical part of the terminal antennomere is also slightly constricted, but it lacks the ring of short setae. However, remnants of such a setal ring can be seen in the antennal club of Trurlia insana. The antennal club in these two species is also constricted near the middle, revealing an indistinct border between fused antennomeres 10 and 11 .

The microsculpture on the gula typical for the Cephenniini is composed of fine but distinct reticulation with transverse cells. In Trurlia, such a mesh can be seen only on the short anterior part of the gula, while the remaining area is densely covered with oval pupillate punctures. Such punctures, sparser and less conspicuous, can also be found in several undescribed species of Cephennomicrus closely related to $C$. taiwanensis. Moreover, they all have a very short and dense basic vestiture with several long upright lateral setae (Jałoszyński, in prep.).

Another interesting character of Trurlia is a subtriangular group of small pores located near the anterior margin of each eye. In many species of Cephennomicrus a small circular protuberance provided with several pores can be seen in the same area of the head, which is referred to as a "frontal gland" (Jałoszyński, in prep.). In some undescribed genera close to Cephennomicrus these tentative glands are not circular but subtriangular. These pores may be another synapomorphy shared by genera in the Cephennomicrus lineage.

The reduction of the metanotal skeleton and lack of wings in Trurlia is very similar to that seen in apterous species of Cephennodes (e.g., C. vafer Kurbatov, 1995) and Hlavaciellus. In Trurlia, there are no metathoracic wings; the metanotum is very short; the alacristae shortened; the apodemes missing and the posterior part of the metanotum highly reduced, membranous, with the metascutellum and metapostnotum indiscernible. This stage in reduction, with the mesoscutellum and elytra free, can be regarded as moderate, compared to the situation in Cephennium and Nanophthalmus. In these two, apterous genera, not only the alacristae are missing, but the elytra are also fused along the suture and the mesonotum fused to the elytra.

Despite the apparently highly derived features such as the fused antennomeres 10 and 11 , the mesoscutellar foveae, the flattened and very large prosternal process, the foveate sculpture on the venter, and the long setae on the dorsum, Trurlia (and Cephennomicrus) would appear to have a number of characters that can be regarded as primitive. The deep lateral foveae on the mesepimera and metaventrite of Trurlia are an unusual character; no such foveae are described in any other Cephenniini. Traces of such structures can be seen in some species of Cephennomicrus (Jałoszyński, in prep.). These foveae may represent a preserved ancestral state. Unfortunately, similar lateral foveae found in other lineages of the Scydmaenidae (e.g., in Euconnus Thomson, 1859; Cyrtoscydmini) have never been properly studied. The large number of ante-basal foveae on the pronotum, and the accompanying transverse groove, found in Trurlia and Cephennomicrus, may be the result of reducing and subdividing an ancestral entire ante-basal groove marking the internal posterior phragma. The most advanced stage and most derived character states would be a single lateral pit (as in Cephennodes and Hlavaciellus), and finally lack of pits (as in Cephennium and Nanophthalmus). The pair of basal pits on each elytron may also be a primitive character, and the single (sometimes very large) fovea occurring in Cephennium, Nanophthalmus and Cephennodes is likely a result of fusion of two foveae. This hypothesis is supported by the shape of the basal elytral fovea in Hlavaciellus. In dry-mounted specimens a single pit is visible, whereas transparent mounts of disarticulated elytra reveal that this single circular opening is shared by 
two subconical, elongate subcuticular sockets. The six visible abdominal sternites, subequal in length and each covered with setae also seem to represent a primitive feature in the Cephenniini. In the Neotropical genera Pseudocephennium and Paracephennium the abdomen is highly derived, with some sternites strongly shortened and devoid of setae (Jałoszyński, unpublished observations). Highly modified abdominal sternites are also found in some species of Cephennodes (e.g., C. abdominalis Jałoszyński, 2007), but they represent male secondary sexual characters and are probably linked with subcuticular glands.

It remains unclear whether the mandibles in Trurlia represent an ancestral or derived character state. The presence of two teeth in addition to the apical tooth is unique in the Cephenniini, but common in other tribes. Among cephenniines, Cephennodes and Hlavaciellus have only an apical tooth that is long, slender and pointed; Nanophthalmus has a shorter, relatively blunt apical tooth; Cephennium has a blunt subapical tooth in addition to a moderately sharp, short apical tooth; in Cephennomicrus the apical tooth is often inconspicuous, broad and blunt, in some species concealed beneath an additional, large dorsal tooth. Mandibles of other genera of the Cephenniini have not been studied. A single subapical tooth in addition to a slender and long, pointed apical tooth is common in the Eutheiini; a sharp apical tooth with a single (usually small) subapical tooth is also common in the Cyrtoscydmini (e.g., in Euconnus Thomson, 1859; Loeblites Franz, 1986; Elacatophora Schaufuss, 1884). An additional tooth located beneath the subapical tooth can also be found in the Cyrtoscydmini (e.g., in Horaeomorphus Schaufuss, 1889 or Syndicus Motschulsky, 1851). In the Scydmaenini (studied in Scydmaenus Latreille, 1802) the left mandible often has two clearly separated subapical teeth, and the right mandible bears one subapical tooth, but with two apices. In Clidicus Laporte, 1832 (Mastiginae: Clidicini) the mandibles are more complex, with two groups of subapical teeth, each with two or even three apices. Mandibles of Trurlia have characters typical of the Cephenniini, such as long dorsal setae and lack of prostheca, with a feature highly unusual for this tribe - a median tooth. The latter is, however, relatively common in other tribes. Taking into account the possibility of secondary loss and development of teeth on the mandibles, the ancestral combination of characters remains unclear. However, the mouthparts of such genera as Cephennodes or Hlavaciellus seem to have evolved for a highly specialized function, i.e., for feeding on oribatid mites, or similar Acari with hard and glossy exoskeletons. A precise sequence of events is necessary during which specific structures on the mouthparts must become involved: the suction discs on the labium are used to immobilize the prey, then the apical teeth of the mandibles and the sharp mesal edges are used to cut open the cuticle, and the maxillae assisted by lateral setae of the epipharynx participate in transferring the edible contents (predigested by injected secretions) of the mite into the alimentary tract (Schmid,
1988). Despite variably developed mandibles, the labium, lacinia and galea are uniformly developed within the Cephenniini, suggesting a similar mode of action in all genera. Also structures on the epipharynx are typically reduced to small groups of laterally located setae (Hlavaciellus) or entirely missing (Cephennium, Nanophthalmus, Cephennomicrus). In some genera in this tribe the anterior margin of the labrum is provided with a membranous velum [Cephennium, some species of Cephennomicrus, e.g. C. nomurai (Jałoszyński \& Hoshina, 2003)], whose hypothetical function might be sealing the mouthparts around the incised area on the cuticle of the prey, possibly in association with the lateral lobes of the hypopharynx. The diversity in the shape of mandibles seems to be crucial for specializing on different types of prey and possibly also for the strategy of feeding on mites or other tiny animals, but the general mechanism, employing a sequence of actions of the suction discs, followed by piercing and cutting the cuticle, may be similar in all Cephenniini. Assuming that a common mechanism exists, the minimum set of characters necessary for feeding is that seen in Cephennodes and Hlavaciellus, in which the mandibles have a single apical tooth and sharp mesal edge. It remains to be clarified whether this is a primitive state, or a result of reduction of subapi$\mathrm{cal} /$ median teeth possibly present in the common ancestor of all Cephenniini. The mandibles found in Trurlia significantly broadened the spectrum of variants in the tribe. Observations on living beetles are necessary to determine how narrow a range of prey is associated with each type of mandible, and how additional subapical and median teeth in Trurlia and the dorsal tooth in Cephennomicrus alter the action of mandibles compared to simpler structures, like those in Cephennodes.

The morphology of the Neotropical taxa and some new Oriental genera awaiting description is likely to be important for resolving relationships within the Cephenniini; therefore a comprehensive phylogenetic analysis can be undertaken only when these taxa have been appropriately treated.

ACKNOWLEDGEMENTS. My thanks go to W. Schawaller (SMNS), who issued a loan used in this study; S. Nomura (NSMT), who provided additional material and helped in many ways during my stay in Japan, where a major part of this paper was prepared; and A. Newton (Field Museum of Natural History, Chicago, USA) for reading an early draft of this manuscript.

\section{REFERENCES}

CsIKI E. 1909: Újabb adatok Magyarorzág bogárfaunájához [New additions to the Hungarian beetle fauna]. Rovart. Lap. 16: 3-6.

Franz H. 1983: Scydmaeniden des Ungarischen Naturwissenschaftlichen Museums in Budapest aus Südostasiens: Sri Lanka, Thailand und Vietnam. Folia Entomol. Hung. 54: 175-187.

Franz H. 1986: Ein neues Genus und ein neues Subgenus der Scydmaenidae (Coleoptera) aus Südost-Asien. Rev. Suisse Zool. 93: 965-970. 
JAŁOSZYŃSKi P. 2004: A new species of Neseuthia Scott (Coleoptera, Scydmaenidae) from Taiwan. Genus 15: 157-161.

JAŁOSZYŃSKI P. 2006: A new genus of the Cephenniini (Coleoptera, Scydmaenidae) from Borneo, with description of Hlavaciellus vampirus n. sp. Genus 17: 67-74.

JAŁOSZYŃSKi P. 2007a: The Cephenniini (Coleoptera, Scydmaenidae) of China. II. Cephennodes Reitter of southern provinces, with taxonomic notes on the Cephennodes-Chelonoidum complex (Coleoptera, Scydmaenidae). Genus 18: 7-101.

JAŁOSZYŃSKI P. 2007b: The Cephenniini (Coleoptera, Scydmaenidae) of China. III. Cephennodes Reitter of Sichuan and Shaanxi. Genus 18: 151-207.

JAŁOSZYŃSKI P. \& HoshinA H. 2003: Four new species of the genus Neseuthia Scott, 1922 (Coleoptera, Scydmaenidae) from Japan. Jap. J. Syst. Entomol. 9: 47-62.

JAŁOSZYŃSKi P. \& NomURA S. 2008: A new Cephennomicrus (Coleoptera, Scydmaenidae) from the Malay Peninsula. Elytra 36: 153-157.

JaŁoszyński P., Arai S. \& Arai K. 2004: A new species and subspecies of Neseuthia Scott (Coleoptera, Scydmaenidae) from Okinawa Island, Japan. Elytra 32: 57-64.

Kurbatov S.A. 1995: Sur les Euthiini et Cephenniini (Coleoptera, Scydmaenidae) de l'Extrême-Est de la Russie et du Japon. Rev. Suisse Zool. 102: 943-959.

LAPORTE F.L. 1832: Mémoire sur cinquante espèces nouvelles ou peu connues d'insectes. Ann. Soc. Entomol. Fr. 1: 386-415.

Latreille P.A. 1802: Histoire Naturelle, Générale et Particulière des Crustacés et des Insectes. Familles Naturelles des Genres. Vol. 3. F. Dufart, Paris, xii +467 pp.

Leschen R.A.B. \& Beutel R.G. 2004: Ocellar atavism in Coleoptera: plesiomorphy or apomorphy? J. Zool. Syst. Evol. Res. 42: 63-69.

Motschulsky V. 1851: Énumération des nouvelles espèces de Coléoptères. Bull. Soc. Imp. Natur. Moscou 24: 479-511.
Müller P.W.I. \& Kunze G. 1822: Monographie der Ameisenkäfer (Scydmaenus Latreille). Schrift. Naturforsch. Ges. Leipzig 1: 175-204, pl. 5.

O'Keefe S.T. 1999: The Scydmaenidae of Costa Rica. I. Leptochromus Motschulsky, Eutheia Stephens, and Paracephennium gen. n. (Coleoptera: Scydmaenidae). Kol. Rundsch. 69: $67-81$.

ReITTER E. 1882: Bestimmungs-Tabellen der europäischen Coleopteren. V. Enthaltend die Familien: Paussidae, Clavigeridae, Pselaphidae und Scydmaenidae. Verh. Zool.-Botan. Ges. Wien 31[1881]: 443-592.

ReitTer E. 1883: Neue Pselaphiden und Scydmaeniden aus Central und Sudamerika. Verh. Zool.-Botan. Ges. Wien 32[1882]: 371-386.

ReitTer E. 1884: Beitrag zur Pselaphiden- und ScydmaenidenFauna von Java und Borneo. II. Verh. Zool.-Botan. Ges. Wien 33[1883]: 387-428.

ReitTer E. 1907: Verzeichnis der von Dr. F. Eichelbaum im Jahre 1903 in Deutsch-Ostafrika gesammelten Scydmaeniden (Col.). Wien. Entomol. Ztg 26: 297-305.

Schaufuss L.W. 1884: Die Scydmaeniden nord-ost-Africa's, der Sunda-Inseln und Neu-Guinea's im Museo Civico di Storia Naturale zu Genua. Ann. Mus. Civ. St. Nat. Genova 1(21): 387-424.

Schaufuss L.W. 1889: Neue Scydmaeniden im Museum Ludwig Salvator. Berl. Entomol. Z. 33: 1-42.

SCHMID R. 1988: Morphologische Anpassungen in einem Rauber-Beute-System: Ameisenkafer (Scydmaenidae, Staphylinoidea) und gepanzerte Milben (Acari). Zool. Jb. Abt. Syst. Ökol. Geogr. Tiere 115: 207-228.

Thomson C.G. 1859: Skandinaviens Coleoptera, Synoptiskt Bearbetade. Vol. 1. Berlingska Boktrykeriet, Lund, 290 pp.

Received November 5, 2008; revised and accepted February 23, 2009 